\title{
Distribution and Molecular Characterization of an Alien Fungus, Clathrus archeri, in Poland
}

\author{
Marcin Pietras $^{1 *}$, Maria Rudawska ${ }^{1}$, Grzegorz Iszkuło ${ }^{1,2}$, \\ Anna Kujawa ${ }^{3}$, Tomasz Leski ${ }^{1}$ \\ ${ }^{1}$ Institute of Dendrology, Polish Academy of Sciences, \\ Parkowa 5, 62-035 Kórnik, Poland \\ ${ }^{2}$ Faculty of Biological Sciences, University of Zielona Gora, \\ Szafrana 1, 65-516 Zielona Gora, Poland \\ ${ }^{3}$ Institute for Agricultural and Forest Environment, Polish Academy of Sciences, Field Station in Turew, \\ Szkolna 4, Turew, 64-000 Kościan, Poland
}

Received: 11 October 2015

Accepted: 30 December 2015

\begin{abstract}
Clathrus archeri is a saprotrophic fungus native to Australia and New Zealand and known in Europe since the beginning of the $20^{\text {th }}$ century. In Poland, C. archeri was recorded for the first time in 1973 and since then basidiomata of this fungus have been recorded almost 90 times, mostly in the southern part of the country. In the present study, we update the distribution of $C$. archeri in Poland and include the latest records from Central Poland. We show a significant increase in the number of $C$. archeri observations in recent years $\left(\mathrm{R}^{2}=0.400, \mathrm{p}<0.001\right)$. Our research shows that precipitation should be regarded as an important factor in the spread of $C$. archeri. Additionally, intraspecific genetic variability of nrRNA of $C$. archeri from different localities in Poland has been determined. Obtained results indicate zero to low levels of diversity in the nrITS and nrLSU sequences obtained from 16 C. archeri basidiomata from different localities in Poland (evolutionary divergence between sequences up to 0.002 and 0.001 for nrITS and nrLSU, respectively). Finally we identify some limitations in this research and make suggestions for future studies of pathways of the distribution of this fungus in the new area.
\end{abstract}

Keywords: foreign fungus, fungal biogeography, genetic diversity, molecular markers

\section{Introduction}

Introductions and the spread of alien and often invasive organisms is one of the most important problems

$\overline{\text { *e-mail: mpietras@man.poznan.pl }}$ in nature conservation [1]. For a long time, studies on anthropogenic introductions have mainly focused on plant and animal invasive species [2]. The invasion ecology of fungi has attracted much less attention. Meanwhile, fungi represent an essential biodiversity component, not only because of their ecological significance but also for their exceptionally high species richness, conservatively 
estimated at 1.5 million species [3]. Existing studies of fungi invasion biology mostly concentrate on pathogens, probably because the direct effect of pathogenic organisms occurring in novel ranges is easily perceptible and the negative economic consequences can be remarkable. Five highly pathogenic species of fungi are on the list of One Hundred of the World's Worst Invasive Alien Species [4]. Among non-pathogenic fungi, more detailed descriptions of invasion patterns have only been published for a few ectomycorrhizal fungi $[5,6]$. Aside from the well-described pathways of the distribution of a woodinhabiting species, Favolaschia calocera [7], very little is known about the abundance and spread of foreign saprotrophic fungi. Also, knowledge about the genetic variability of fungal populations outside their natural range remains scant. Using ITS analysis, Vizzini et al. [7] have shown potential invasion routes of $F$. calocera into Europe and suggest ITS as an effective phylogeography molecular marker. However, studies of genetic structures of fungi in the new area is often more complicated duo to different events during the first phase of introduction (e.g., multiple introduction, random genetic drift, or selection exerted by the novel environment) $[8,9]$.

Of the 89 taxa of foreign fungi published in the Polish list of non-native organisms [10], the vast majority are pathogens. Of the eight non-pathogenic fungi in this database, most (six) belong to the order Phallales and include two Clathrus species: C. archeri (Berk.) Dring (octopus stinkhorn or devil's finger) and C. ruber Mich. ex Pers. (latticed stinkhorn). According to the Dictionary of Fungi, the Clathrus genus (Clathraceae, Phalalles) comprises 16 species, which are mainly found in subtropical and tropical regions [11]. Clathrus ruber is a Mediterranean fungus that extends into central and northern Europe. In Poland, it has only been recorded three times [12]. In contrast, C. archeri basidiomata are quite frequently recorded in Poland. The characteristic $C$. archeri basidiomata emerge from a gelatinous egg-like structure after prolonged periods of wet weather. Young basidioma rupture with the elongation of four to eight pink-to-red arms, coated with a dark foulsmelling tissue. It is generally assumed that $C$. archeri is native to Australia and New Zealand and has been gradually spreading throughout the world [13]. The occurrence of $C$. archeri in Europe has been known since the beginning of the $20^{\text {th }}$ century; it was first recorded in 1914 in France. Presumably, this species has been transported to Europe with Australian wool [13] or, alternatively, with military supplies at the beginning of the First World War [14].

In Poland, $C$. archeri was recorded for the first time in 1973 in southern Poland [12]. Its basidiomata have been recorded almost 90 times since then, mostly in the southern part of the country. However, all reports on the distribution of $C$. archeri in Poland are embedded in the gray literature [15-17], and are therefore not easily available to a wider audience.

Both edaphic and climatic factors, mostly precipitation, are considered essential for fungi fruiting and/or fungal species distribution across landscapes [18]. In the present study, we update the distribution of $C$. archeri in Poland and include the latest records from Central Poland. In addition, we have correlated $C$. archeri distribution with the precipitation data. We hypothesize that precipitation is an important driver of C. archeri basidiomata's appearance and thus may stimulate the spread of this fungus in Poland.

Advances in molecular techniques using internal transcribed spacer (ITS) regions of nuclear ribosomal DNA (nrRNA) and nuclear large subunits (nrLSU) have made it possible to investigate fungal diversity at the molecular level $[19,20]$. To date, knowledge of the genetic variability of $C$. archeri remains scant. Therefore, the second aim of this study was to analyze intraspecific variability in the nrITS and nrLSU regions of nrRNA amplified from all available $C$. archeri specimens deposited and preserved in the Polish Fungal Herbaria. We used phylogenetic analysis to compare the sequences obtained and to molecularly identify the basidiomata collected. For the first time, a set of $C$. archeri nrITS and nrLSU rRNA sequences have been deposited in a public database.

\section{Materials and Methods}

\section{Clathrus archeri Distribution in Poland}

The distribution of $C$. archeri in Poland was compiled on the basis of an intensive search of Polish mycological data, published in the non-English literature. Four sources with a broad overview of records [15-17, 21] were used to prepare a $C$. archeri distribution map. The map was updated with recent records by non-professional mycologists saved in the Database of Protected and Endangered Mushroom Species (http:/www.grzyby.pl/ gatunki/Clathrus archeri.htm), and one new localities found in 2009, 2012, and 2014 by the first author in central Poland. If a record did not have detailed geographical data (latitude, longitude), these data were inferred from information provided on the accession using Google Earth (Version 7.1.2.2041; Google Inc., Mountainview, CA, USA). The distribution of $C$. archeri in Poland was analyzed against the precipitation data obtained from the WorldClim database (www.worldclim.org) using DIVA-GIS software for each point using 2.5-min resolution interpolated climatic surfaces [22]. Simple linear regression was used to show the relationship between consecutive years and the number of $C$. archeri observations in each year (Jmp 8.0 software (SAS Institute Inc., Cary, NC, USA)). A model of the suitable niche distribution was created to distinguish the climatic factors limiting occurrence of $C$. archeri in Poland (Maxent 3.3.2) [23, 24]. Input data were 19 climatic variables [22] and all records of $C$. archeri gathered in this study. The evaluation of the model was carried out using the most common metrics - area under the curve (AUC), where 1 describe perfect model, and values more than 0.9 indicate high performance of the model. 
Table 1. Collection data and GenBank accession numbers for nrITS and nrLSU sequences of the Clathrus archeri basidiomata used in this study.

\begin{tabular}{|c|c|c|c|c|c|c|}
\hline & $\begin{array}{l}\text { Collection } \\
\text { Sites }\end{array}$ & Coordinates & $\begin{array}{l}\text { Collection } \\
\text { Dates }\end{array}$ & Herbarium & $\begin{array}{l}\text { Voucher } \\
\text { Specimens }\end{array}$ & $\begin{array}{l}\text { Accession numbers } \\
\text { nrITS/nrLSU }\end{array}$ \\
\hline $1 *$ & Bukowiec & $\begin{array}{l}49,438467 \\
20,615102\end{array}$ & 1983 & $\begin{array}{c}\text { Institute of Botany, Jagiellonian } \\
\text { University, Kraków }\end{array}$ & KRA F-1983-7 & ---/--- \\
\hline 2 & Las Mokrzańki & $\begin{array}{l}51,179500 \\
16,872741\end{array}$ & 2005 & $\begin{array}{l}\text { Museum of Natural History } \\
\text { Wrocław University, Wrocław }\end{array}$ & 344 & $\underline{\text { KJ702370/KJ702379 }}$ \\
\hline 3 & $\begin{array}{c}\text { Budy } \\
\text { Głogowskie }\end{array}$ & $\begin{array}{l}50,153531 \\
21,897125\end{array}$ & 2006 & $\begin{array}{l}\text { Institute of Agricultural and Forest } \\
\text { Environment PAS, Turew }\end{array}$ & ID 46421 & $\underline{\text { KJ702366 }} \underline{\text { KJ702375 }}$ \\
\hline 4 & Huta Polańska & $\begin{array}{l}49,463550 \\
21,533890\end{array}$ & 2006 & $\begin{array}{c}\text { Institute of Agricultural and Forest } \\
\text { Environment PAS, Turew }\end{array}$ & ID 45775 & $\underline{\text { KJ702367/KJ702376 }}$ \\
\hline 5 & Dobropole & $\begin{array}{l}53,162135 \\
15,212903\end{array}$ & 2006 & $\begin{array}{l}\text { Marzena Łyczek private } \\
\text { collection, Szczecin }\end{array}$ & ID 45343 & $\underline{\text { KJ702369/KJ702378 }}$ \\
\hline 6 & Paszów & $\begin{array}{c}50,09702 \\
18,137108\end{array}$ & 2006 & University of Kielce & C_A001 & $\underline{\text { KP688375/KP688382 }}$ \\
\hline 7 & Nieborowice & $\begin{array}{l}50,227167 \\
18,589897\end{array}$ & 2008 & $\begin{array}{l}\text { Institute of Agricultural and Forest } \\
\text { Environment PAS, Turew }\end{array}$ & ID 109932 & $\underline{\text { KJ702365 }} \underline{\text { KJ702374 }}$ \\
\hline 8 & Siedlec & $\begin{array}{l}51,485954 \\
17,065851\end{array}$ & 2009 & $\begin{array}{c}\text { Institute of Dendrology PAS } \\
\text { Kórnik }\end{array}$ & ID PAN O14 & $\underline{\text { KJ702363/KJ702372 }}$ \\
\hline 9 & Osolin & $\begin{array}{l}51,342002 \\
16,835023\end{array}$ & 2010 & $\begin{array}{l}\text { Museum of Natural History } \\
\text { Wrocław University, Wrocław }\end{array}$ & 347 & $\underline{\text { KJ702371 }} \underline{\text { KJ702380 }}$ \\
\hline 10 & Osolin & $\begin{array}{l}51,342001 \\
16,835023\end{array}$ & 2010 & $\begin{array}{l}\text { Museum of Natural History } \\
\text { Wrocław University, Wrocław }\end{array}$ & 345 & $\underline{\text { KJ702368 }} \underline{\text { KJ702377 }}$ \\
\hline 11 & Kotków & $\begin{array}{l}52,217441 \\
19,047546\end{array}$ & 2011 & $\begin{array}{l}\text { Institute of Agricultural and Forest } \\
\text { Environment PAS, Turew }\end{array}$ & ID 189978 & $\underline{\text { KJ702364 }} \underline{\text { KJ702373 }}$ \\
\hline 12 & Siedlec & $\begin{array}{l}51,485954 \\
17,065851\end{array}$ & 2012 & $\begin{array}{c}\text { Institute of Dendrology PAS } \\
\text { Kórnik }\end{array}$ & C_A002 & $\underline{\text { KP688376/KP688383 }}$ \\
\hline 13 & Świetnica & $\begin{array}{l}49,52182 \\
17,13871\end{array}$ & 2013 & $\begin{array}{c}\text { Institute of Dendrology PAS } \\
\text { Kórnik }\end{array}$ & C_A003 & $\underline{\text { KP688377/KP688384 }}$ \\
\hline 14 & Wieliczka & $\begin{array}{c}49,965355 \\
20,0939941 \\
\end{array}$ & 2014 & $\begin{array}{c}\text { Institute of Dendrology PAS } \\
\text { Kórnik }\end{array}$ & C_A004 & $\underline{\text { KP688378/KP688385 }}$ \\
\hline 15 & Marwice & $\begin{array}{l}52,78025 \\
15,08525\end{array}$ & 2014 & $\begin{array}{c}\text { Institute of Dendrology PAS } \\
\text { Kórnik }\end{array}$ & C_A005 & $\underline{\text { KP688379/KP688386 }}$ \\
\hline 16 & Muchów & $\begin{array}{l}51,0088945 \\
15,9895706\end{array}$ & 2014 & $\begin{array}{c}\text { Institute of Dendrology PAS } \\
\text { Kórnik }\end{array}$ & C_A006 & $\underline{\text { KP688380/KP688387 }}$ \\
\hline 17 & Siedlec & $\begin{array}{l}51,485954 \\
17,065851\end{array}$ & 2014 & $\begin{array}{c}\text { Institute of Dendrology PAS } \\
\text { Kórnik }\end{array}$ & C_A007 & $\underline{\text { KP688381/KP688388 }}$ \\
\hline
\end{tabular}

*omitted from analysis because of the low quality of the nrITS and nrLSU sequences obtained from basidiome KRA F-1983-7.

\section{Molecular Analysis}

Samples used for molecular analyses originated from two sources: from four Polish Herbaria specialized in preserving vouchers of fungi and from specimens collected by the first author and different mushroom amateurs during field forays conducted in Poland in 2009-14 (Table 1). Altogether only 17 available basidiomata of $C$. archeri out of 90 records from different localities in Poland appear to be available and could be used in this study. Basidiomata collected in the field were examined using macro- and micro-morphological observations, dried, labeled, and preserved in the Institute of Dendrology Polish Academy of Sciences (voucher numbers are listed in Table 1). DNA was extracted from each basidioma using a miniprep method developed by Gardes and Bruns [25]. Sequences were obtained using the ITS primers: ITS1f and ITS4 [26] and the nrLSU primers: Ctb6 (GCATATCAATAAGCGGAGG) and TW13 (GGTCCGTGTTTCAAGACG). The other polymerase chain reaction (PCR) reagents and their final concentrations were as follows; $20 \mathrm{mM}$ Tris- $\mathrm{HCl}$ (pH8.4), $50 \mathrm{mM} \mathrm{KCl}, 2.5 \mathrm{mM} \mathrm{MgCl} 2,0.05 \% \mathrm{~W}-1$ (Qiagen), $200 \mathrm{mM}$ ultra-pure dATP, dCTP, dGTP, and dTTP (Qiagen), and 1.75 units Taq DNA polymerase (Qiagen). The following thermal profile was used: initial $3 \mathrm{~min}$ at $94^{\circ} \mathrm{C}$, followed by 35 cycles of $1 \mathrm{~min}$ at $94^{\circ} \mathrm{C}, 1 \mathrm{~min}$ at $56^{\circ} \mathrm{C}\left(54^{\circ} \mathrm{C}\right.$ for $\mathrm{Ctb} 6$ and $\mathrm{TW} 13$ ), and 3 min at $72^{\circ} \mathrm{C}$ (up to 10-min increment time in final extension) [27]. Two independent DNA isolations were obtained from each specimen. From each template four PCRs were carried out: two 
each for the nrITS and nrLSU regions. The PCR products were sequenced in both directions using the primers ITS1F/ITS4 (for ITS fragment) and Ctb6/TW 14 (for LSU) at the Laboratory of Molecular Biology of Adam Mickiewicz University (Poznań).

The sequences obtained were verified visually on chromatograms using BIOEDIT [28], and a consensus sequence of each basidioma was made. The best-fit model of nucleotide substitution was selected separately for the nrITS and nrLSU fragments using JModelTest 2.1. For both markers the selected model was GTR $+\mathrm{I}+\mathrm{G}$. Genetic distances between aligned nrITS and nrLSU sequences were calculated in MEGA 4 software using the maximum

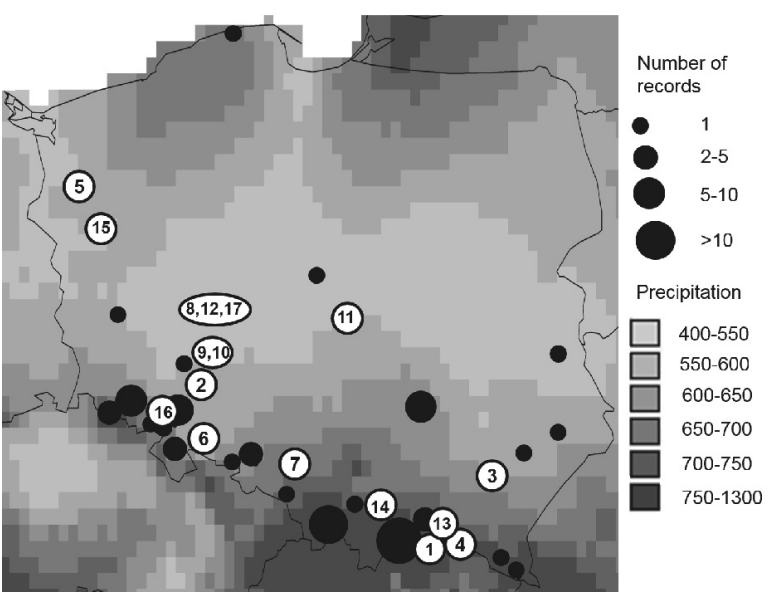

Fig. 1. The distribution of Clathrus archeri in Poland against a background of mean annual precipitation $(\mathrm{mm})$. The size of the black circles is proportional to the number of records, numbers 1-17 $=$ vouchers analyzed (each number represents one single specimen; see Table 1).

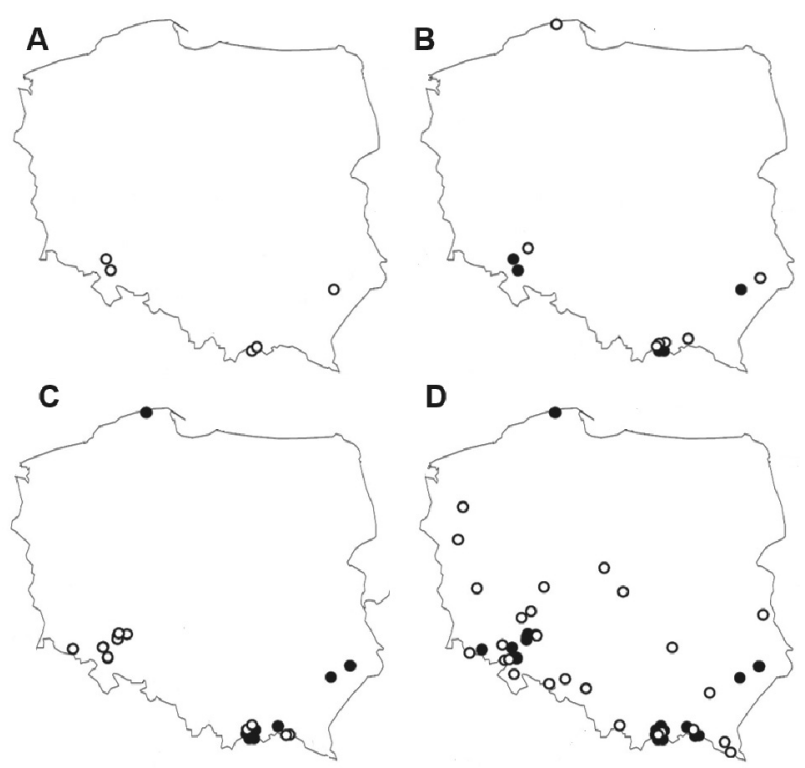

Fig. 2. Distribution of Clathrus archeri in Poland from 1973 to 2014 (A: 1973-1983; B: 1984-1993; C: 1994-2003; D: 2004-14); blank circles represent new records in a given period. composite likelihood method [29]. Phylogenetic tree of ITS sequences was inferred using the neighbor-joining method using MEGA 4 software based on sequences obtained in this study and closely related species retrieved from Genbank. Both nrITS and nrLSU sequences have been deposited in GenBank. Their accession numbers are listed in Table 1.

\section{Results and Discussion}

Clathrus archeri is a foreign but commonly recorded fungal species in Europe, especially in areas with a temperate oceanic climate. Since the 1970s, C. archeri basidiomata have been recorded in Poland in several dozen localities. The maps of $C$. archeri records (Figs 1,2) show a typical distribution pattern for introduced organisms in their invasive range $[7,30,31]$ with numerous records representing the initial phase of introduction (southern Poland) and only a few records in recently settled areas (central and northern Poland). Such a distribution pattern suggests that $C$. archeri is spreading from south to north in Poland and reveals possibly the invasive characteristics of the expansion. This is further confirmed by a significant increase in the number of $C$. archeri observations in recent years (Fig. 3, $\mathrm{R}^{2}=0.400, \mathrm{p}<0.001$ ).

The occurrence and further expansion of $C$. archeri in Poland seems to be closely related with climate conditions (mostly annual precipitation) and confirms the earlier opinions expressed by other authors on the hydrophilic character of this species [13]. Up to $80 \%$ of $C$. archeri recordings in Poland are concentrated in the uplands and mountains where annual precipitation is greater than $600 \mathrm{~mm}$ (Fig. 1). In contrast, for many years C. archeri has not been recorded in Central Poland, where mean annual precipitation reaches $550 \mathrm{~mm}$. This assumption was weakened by the unexpected discovery in July 2009 of basidiomata of $C$. archeri found by the first author in an oak forest near Siedlec village (Forestry Management Piaski), situated in the Wielkopolska lowland. This

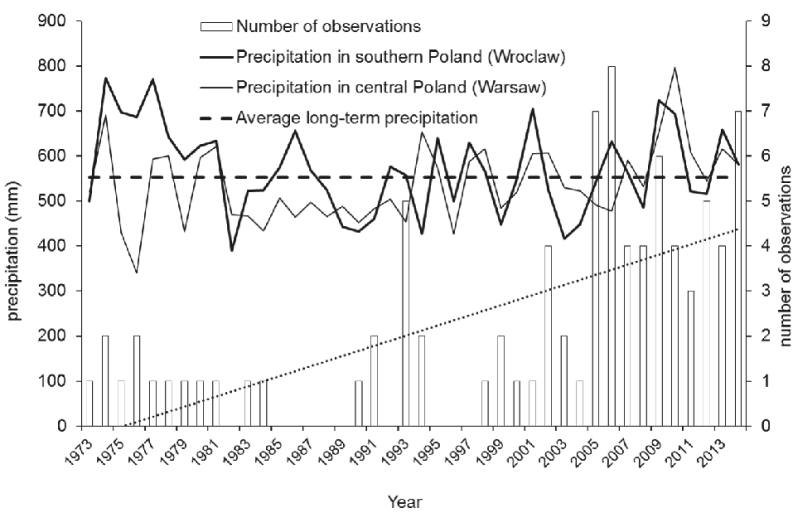

Fig. 3. The number of Clathrus archeri observations and average rainfall in central (Warsaw) and southern (Wroclaw) Poland in 1973-2014. The dotted line is a regression between years and number of observations $\left(\mathrm{R}^{2}=0.400, \mathrm{p}<0.001\right)$. 
Table 2. Estimates of relative contributions of the environmental variables to the Maxent model created on Polish records of Clathrus archeri $(\mathrm{AUC}=0.993)$.

\begin{tabular}{|c|c|c|}
\hline $\begin{array}{c}\text { Variable } \\
\text { number }\end{array}$ & Description & Percentage \\
\hline Var_1 & Precipitation of driest month & 25.6 \\
\hline Var_2 & Mean temperature of driest month & 24.5 \\
\hline Var_3 & Precipitation seasonality & 13.6 \\
\hline Var_4 & $\begin{array}{c}\text { Min. temperature of coldest } \\
\text { month }\end{array}$ & 13.4 \\
\hline Var_5 & Temperature annual range & 9.6 \\
\hline
\end{tabular}

region of Poland is characterized by low annual rainfall $(500-550 \mathrm{~mm})$ and high precipitation deficit. However, summer 2009 (the year of survey) in Wielkopolska lowland was an exceptionally wet season. The total monthly rainfall for June 2009 was $110 \mathrm{~mm}$, almost twice the average monthly rainfall $(59.5 \mathrm{~mm})$ for the closely situated Poznan meteorological station (http://eca.knmi. nl/dailydata/index.php). On several occasions, the forest floor in the oak forest where the $C$. archeri basidiomata were found has been temporarily flooded. In the same time observations of $C$. archeri basidiomata have been made in an oak forest located approximately $20 \mathrm{~km}$ east of the first site (Z. Sierota, personal communication). In subsequent years, $C$. archeri basidiomata have always been found in this region after prolonged precipitation (Aug. 2010 and 2012, and Sept. 2014). Thus, our observation shows that precipitation should be regarded as an important factor in the spread of $C$. archeri. Several other authors have also argued that the productivity of epigeous species of fungi is linked to annual climate conditions, such as the average monthly or annual precipitation [18, 32]. The absence of a relationship between the occurrence of C. archeri and precipitation data in the years 1973-1990 could be because of the low number of records connected with the initial phase of introduction. In subsequent years, chiefly since the beginning of the 21 st century, the number of $C$ archeri observations has increased (Figs 2,3). For the period 2003-14, a clear trend between the number of observations and precipitation has been observed (Fig. 3). Our assumption that the spread of C. archeri may be connected with precipitation is supported by results of the suitable niche distribution model that reveal climatic conditions (precipitation and mean temperature) during the driest month as a major driver of the occurrence of C. archeri basidioma in Poland (Table 2). However, more data are required to provide stronger statistical support of the relationship between precipitation and the spread of $C$ archeri in Poland.

The unforeseen finding of $C$. archeri basidiomata in June 2009 in the Wielkopolska lowland created an impulse to study the genetic diversity of this fungus in Poland. Unfortunately, owing to its spectacular appearance, most of the $C$. archeri observations have not been backed up by specimens in herbaria because reliable identification of basidioma is easy in the field. The strong foul odor of mature basidioma may be an additional reason for the scarcity of $C$. archeri in collections. Therefore, despite the relatively large number of $C$. archeri observations in Poland, only 10 specimens of the fungus have been preserved in Polish herbaria (Table 1 and Fig. 1), and the next seven were collected especially for purposes of this research. Altogether the fungal DNA was extracted from 17 specimens originating from a whole range of $C$. archeri in Poland (Table 1). Amplification of nrITS and nrLSU was successful from 16 specimens and generated a single PCR product 543 and $855 \mathrm{bp}$ for nrITS and nrLSU, respectively. Both the nrITS and nrLSU sequences obtained from voucher KRA F-1983-7 (No. 1 in Table 1 and on Fig. 1) were low quality and were excluded from further analysis. This may have been because of the longterm storage of the basidioma (since 1983); the success of DNA sequencing is highly dependent upon the age of the specimen [33].

Both the nrITS and nrLSU sequences amplified from 16 basidiomata of $C$. archeri were used to investigate if any interspecimen genetic variability exists in the examined area. The overall mean genetic distance was 0.002 and 0.001 for the nrITS and nrLSU sequences, respectively. Nuclear ITS and nrLSU variants were distinguished based on pairwise comparisons of genetic distances between all of the sequences tested (both nrITS and nrLSU). The range of genetic distances between obtained nrITS sequences varied from 0.000 to 0.009 . The highest sequence variability was observed between specimen Nos. 9 and 10 (basidiomata collected in Osolin near Wroclaw) and the rest of the specimens. The sequence variability in the nrLSU region ranged from complete identity to divergence at 0.002 . Sequences analysis yielded seven variable sites in the amplified nrLSU region (Table 3).

The comparison of the aligned sequences obtained from 16 specimens indicated a lack of or extremely low genetic differentiation among analyzed specimens. Such levels of fungal genetic diversity are situated in the accepted intraspecific range of variability for nrITS and nrLSU, which accounts for 3\% in nrITS and no more than $1 \%$ in $\operatorname{nrLSU}[34,35$, Tedersoo personal communication]. Further comparisons of the genetic variability of Polish $C$. archeri specimens with data from other parts of the world are impossible because sequences of $C$. archeri are completely lacking in public databases. Thus, at that moment both molecular markers used in our study could not be effectively utilized to evaluate the possible route of C. archeri introduction into Europe. Recently, nrITS sequence-based analyses have been applied in resolving the origin of Italian strains of the paleotropical wood inhabiting fungus Favolaschia calocera [7], and revealed that the first Italian $F$. calocera specimens arrived to Italy from New Zealand. Low genetic differentiation within $C$. archeri nrITS sequences obtained in our investigation express doubts concerning the helpfulness of ITS in studies describing $C$. archeri biogeography and introductions. On the other hand, low genetic variability of $C$. archeri sequences is placed in seven variable sites in the $\mathrm{nrLSU}$ 
Table 3. Observed variables in the nrLSU of 16 Clathrus archeri basidiomata.

\begin{tabular}{|c|c|c|c|c|c|c|c|c|}
\hline \multirow{2}{*}{ No. } & \multirow{2}{*}{ Accession number } & \multicolumn{7}{|c|}{ Nucleotide position } \\
\hline & & 25 & 208 & 518 & 615 & 633 & 715 & 775 \\
\hline 2 & $\underline{\text { KJ702379 }}$ & . & G & $\mathrm{C}$ & $\mathrm{T}$ & . & $\mathrm{T}$ & A \\
\hline 3 & $\underline{\text { KJ702375 }}$ & . & . & $\mathrm{G}$ & A & . & G & G \\
\hline 4 & $\underline{\text { KJ702376 }}$ & . & . & $\mathrm{G}$ & A & . & G & G \\
\hline 5 & $\underline{\text { KJ702378 }}$ & A & . & G & A & A & G & G \\
\hline 6 & $\underline{\text { KP688382 }}$ & . & A & G & A & . & G & G \\
\hline 7 & $\underline{\text { KJ702374 }}$ & . & . & G & A & . & G & G \\
\hline 8 & $\underline{\text { KJ702372 }}$ & . & . & G & A & . & G & G \\
\hline 9 & $\underline{\text { KJ702380 }}$ & A & A & G & $\mathrm{T}$ & A & G & G \\
\hline 10 & $\underline{\text { KJ702377 }}$ & . & A & G & A & . & G & G \\
\hline 11 & $\underline{\text { KJ702373 }}$ & . & . & $\mathrm{G}$ & A & . & G & G \\
\hline 12 & $\underline{\text { KP688383 }}$ & . & . & G & A & . & G & G \\
\hline 13 & $\underline{\text { KP688384 }}$ & . & A & $\mathrm{G}$ & A & . & G & G \\
\hline 14 & $\underline{\text { KP688385 }}$ & . & A & G & A & . & G & G \\
\hline 15 & $\underline{\text { KP688386 }}$ & . & A & G & A & . & G & G \\
\hline 16 & $\underline{\text { KP688387 }}$ & . & A & G & A & . & G & G \\
\hline 17 & $\underline{\text { KP688388 }}$ & . & . & $\mathrm{G}$ & A & . & G & G \\
\hline
\end{tabular}

region (Table 3). Nuclear LSU is a genetic marker commonly used in phylogenetic studies. But within-species genetic variability in nrLSU may suggest a different origin of population as a consequence of geographical separation of species in native sub-ranges. Unfortunately, in the case of $C$. archeri we currently have no data that might be used to better understand the history and spread of $C$. archeri.

In our study, we used neighboring nrITS and nrLSU rRNA (approximately 1,400 bp in total) regions to investigate within-species diversity of $C$. archeri basidiomata. Providing a sufficient number of sequences will offer promising opportunities to design nrITS and/or nrLSU rDNA $C$. archeri-specific primers for monitoring of the spread of this fungus in new areas. Species-specific primers may open the way to directly studying the occurrence of $C$. archeri mycelium in environmental samples (soil samples) regardless of the ephemeral production of fruiting structures. We believe that a molecular phylogeographic approach will provide remarkable new insights into the distribution of $C$. archeri and other invasive fungi and allow the reconstruction of their migration history in the near future. However, in the analysis of intraspecific variation of fungi, molecular studies should go hand in hand with morphological and microscopic approaches [36]. The existence of different varieties in $C$. archeri has been noted in the literature [37], but until now the potential relationship between morphological features and genetic differences have not been studied. Therefore, systematic surveys of $C$. archeri basidiomata in and beyond its natural range that employ both morphological and genetic techniques are urgently required.

\section{Conclusion}

The occurrence of $C$. archeri in Poland seems to be closely related with climatic conditions, mostly with annual precipitation. However, more data are necessary to provide stronger statistical support of this relationship. Analyzed specimens of $C$. archeri indicated low genetic differentiation within nrITS and nrLSU fragments. On the other hand, within-species genetic variability in nrLSU may suggest a different origin of populations and the same recommend nrLSU as a useful marker in biogeographical studies of fungi.

Future morphological and molecular inventory data will constitute a baseline for further investigations into C. archeri biogeography, ecology, and invasion biology, including how the introduction of this fungus impacts native fungal communities.

\section{Acknowledgements}

The authors thank Monika Dering for her comments on a previous draft of the manuscript and Leho Tedersoo for valuable assistance with phylogenetic data. Special thanks to Marzena Łyczek, Bożena Muszyńska, Aleksandra Ćwiejkowska, Winicjusz Kasprzak, and Jan Zieliński 
for help in specimen gathering. This study was partly supported the Polish National Science Center (according to decision No. DEC-2011/03/N/NZ9/04562) and by the Polish Ministry of Science and Higher Education within support for young scientists of the Institute of Dendrology of the Polish Academy of Sciences in 2013.

\section{References}

1. VITOUSEK P.M., D'ANTONIO C.M., LOOPE L.L., REJMÁNEK M., WESTBROOKS R. Introduced species: a significant component of human-caused global change. New Zeal. J. Ecol. 21 (1), 1, 1997.

2. DESPREZ-LOUSTAU M.L., ROBIN C., BUEE M., COURTECUISSE R., GARBAYE J., SUFERT F., SACHE I., RIZZO D.M. The fungal dimension of biological invasions. Trends Ecol. Evol. 22 (9), 472, 2007.

3. HAWKSWORTH D.L., MUELLER G.M. Fungal communities: their diversity and distribution. In: Digthon J, White JF, Oudemans P (eds.), The fungal community: its organization and role in the ecosystem. CRC Press; 27, USA, 2005

4. DESPREZ-LOUSTAU M.L., COURTECUISSE R., ROBIN C., HUSSON C., MOREAU P.A., BLANCARD D., SELOSSE M.A., LUNG-ESCARMANT B., PIOU D., SACHE I. Species diversity and drivers of spread of alien fungi (sensu lato) in Europe with a particular focus on France. Biol. Inv. 12 (1), 157, 2010.

5. DÍEZ J. Invasion biology of Australian ectomycorrhizal fungi introduced with eucalypt plantations into the Iberian Peninsula. Biol. Inv. 7, 3, 2010.

6. PRINGLE A., VELLINGA E.C. Last chance to know? Using literature to explore the biogeography and invasion biology of the death cap mushroom Amanita phalloides (Vaill. ex Fr.:Fr.) Link. Biol. Inv. 8, 1131, 2006.

7. VIZZINI A., ZOTTI M., MELLO A. Alien fungal species distribution: the study case of Favolaschia calocera. Biol. Inv. 11 (2), 417, 2009.

8. DLUGOSCH K.M., PARKER I.M. Founding events in species invasions: genetic variation, adaptive evolution, and the role of multiple introductions. Mol. Ecol. 17 (1), 431, 2008.

9. MONTARRY J., HAMELIN F.M., GLAIS I., CORBIÈRE R., ANDRIVONET D. Fitness costs associated with unnecessary virulence factors and life history traits: evolutionary insights from the potato late blight pathogen Phytophthora infestans. BMC Evol. Biol. 10, 283, 2010.

10. SOLARZ W. Alien species in Poland. http://www.iop. krakow.pl/ias/gatunki/rodzaj-organizmu. 2007.

11. KIRK P.M., CANNON P.F., MINTER D.W., STALPERS J.A. Dictionary of fungi. $10^{\text {th }}$ edition. CABI Publishing, Wallingford; USA, 2010.

12. WOJEWODA W. Checklist of Polish larger Basidiomycetes. Szafer Institute of Botany Polish Academy of Sciences, Kraków, 2003.

13. PARENT G.H., THOEN D., CALONGE F.D. Nouvelles données sur la répartition de Clathrus archeri en particulier dans l'Ouest et le Sud-Ouest de l'Europe. Bull. Soc. Myc. Fr. 116 (3), 241, 2000

14. DESPREZ-LOUSTAU M.L., RIZZO D.M. Fungi. In: Simberloff D, Rejmanek M. (eds.), Encyclopedia of Biological Invasions. University of California Press, Barkeley and Los Angeles; 261, USA, 2011.
15. HALAMA M., RECZYŃSKA K., ŚWIERKOSZ K. Nowe stanowiska Clathrus archeri (Berk.) Dring (Basidiomycota, Phallales) na Dolnym Śląsku. Przyroda Sudetów 13, 93, 2010.

16. KUJAWA A., GIERCZYK B. Rejestr gatunków grzybów chronionych i zagrożonych w Polsce. Część IV. Wykaz gatunków przyjętych do rejestru w roku 2008. Przegląd Przyrodniczy 12, 17, 2011.

17. SZCZEPKOWSKI A., OBIDZIŃSKI A. Obce gatunki sromotnikowatych (Phallaceae) w lasach Polski. Studia i Materiały CEPL 27, 279, 2012.

18. EVELING D.W., WILSON R.N., GILLESPIE E.S., BATAILLÉ A. Environmental effects on sporocarp counts over fourteen years in a forest area. Mycol. Res. 94, 998, 1990.

19. PEAY K.G., KENNEDY P.G., BRUNS T.D. Fungal Community Ecology: A Hybrid Beast with a Molecular Master. BioScience 58, 799, 2012.

20. LIU K.L., PORRAS-ALFARO A., KUSKE CR., EICHORST S.A., XIEA G. Accurate, Rapid Taxonomic Classification of Fungal Large-Subunit rRNA Genes. Appl. Environ. Microbiol. 78 (5), 1523, 2012.

21. WOJEWODA W., KARASIŃSKI D. Invasive macro fungi (Ascomycota and Basidiomycota) in Poland. Biological Invasions in Poland 1, 7, 2010.

22. HIJMANS R.J., CAMERON S.E., PARRA J.L., JONES P.G., JARVIS A. Very high resolution interpolated climate surfaces for global land areas. Int. J. Climatol. 25 (15), 1965, 2005.

23. PHILLIPS S.J., ANDERSON R.P., SCHAPIRE R.E. Maximum entropy modeling of species geographic distributions. Ecol. Model. 190 (3-4), 231, 2006.

24. PHILLIPS S.J., DUDÍK M., SCHAPIRE R.E. A maximum entropy approach to species distribution modeling. Proceedings of the twenty-fist international conference on Machine learning. New York NY: ACM: 655, USA, 2004.

25. GARDES M., BRUNS T.D. ITS-RFLP matching for identification fungi. Meth.Mol. Biol. 50, 177, 1996.

26. WHITE T.J., BRUNS T., LEE S., TAYLOR J. Amplification and direct sequencing of fungal ribosomal RNA genes for phylogenetics. In: Innis MA, Gelfand DH, Sninsky JJ, White TJ (eds), PCR protocols: a guide to methods and applications. Academic Press, San Diego; 315, 1990.

27. PIETRAS M., RUDAWSKA M., LESKI T., KARLIŃSKI L. Diversity of ectomycorrhizal fungus assemblages on nursery grown European beech seedlings. Ann. For. Sci. 70 (2), 115, 2013.

28. HALL T.A. BioEdit: a user-friendly biological sequence alignment editor and analysis program for Windows 95/98/ NT. Nucleic Acids Symposium Series 41, 95, 1999.

29. TAMURA K., NEI M., KUMAR S. Prospects for inferring very large phylogenies by using the neighbor-joining method. Proc. Nat. Acad. Sci. (USA) 101, 11030, 2004.

30. WOLFE B.E., RICHARD F., CROSS H.B., PRINGLE A. Distribution and abundance of the introduced ectomycorrhizal fungus Amanita phalloides in North America. New Phytol. 185 (3), 803, 2010

31. SCHOLLER M., HEMM W., LUTZ M. Erysiphe platani: monitoring of an epidemic spread in Germany and molecular characterization based on rDNA sequence data. Andrias 19, $263,2012$.

32. KREBS C.J., CARRIER P., BOUTIN S., BOONSTRA R., HOFER E. Mushroom crops in relation to weather in the southwestern Yukon. Botany 86 (12), 1497, 2008

33. BROCK P.M, DÖRING H, BIDARTONDO M.I. How to know unknown fungi: the role of a herbarium. New Phytol. 181, (3), 719, 2009. 
34. O'BRIEN H.E., PARRENT J.L., JACKSON J.A., MONCALVO JM., VILGALYS R. Fungal community analysis by largescale sequencing of environmental samples. Appl. Environ. Microbiol. 71 (9), 5544, 2005.

35. TEDERSOO L., SUVIA T., LARSSON H., KÕLJALG U. Diversity and community structure of ectomycorrhizal fungi in a wooded meadow. Mycol. Res. 110 (6), 734, 2006.
36. HIBBETT D.S., OHMAN A., GLOTZER D., NUHN M., KIRK P., NILSSON R.H. Progress in molecular and morphological taxon discovery in Fungi and options for formal classification of environmental sequences. Fungal Biol. Rev. 25 (1), 38, 2011.

37. DRING D.M. Contributions towards a rational arrangement of the Clathraceae. Kew Bull. 35, 1, 1980. 